\title{
Opportunities Abound: Stay Connected to Healthcare Initiatives
}

\author{
Patricia 0'Connor, RN, MSc(A) \\ President, ACEN \\ Associate Director of Nursing, McGill University Health Centre \\ Montreal, QC
}

I want to take this opportunity to wish everyone a pleasant and safe summer! In this issue of the journal, I'd like to give you an update on recent activities of the Academy of Canadian Executive Nurses, as well as other organizations supporting nursing leadership development. So often, nurses remain unaware of important national-level initiatives, for a variety of reasons. There are many websites to which you can subscribe without cost (or "bookmark as favourites") to stay in the loop and to ensure you don't miss important opportunities, such as access to national scholarships, bursaries, research grants and position papers or statements that could help support changes you would like to see in your practice or organization.

\section{Scholarships for Nursing Leadership}

I am delighted to announce the winner of the 2004 ACEN Scholarship for Nursing Leadership: Anne Cooke, from
Victoria, British Columbia. This annual award of $\$ 2,500$ is given to a nurse who is pursuing studies at the master's or doctoral level and preparing for a nursing leadership role within Canada. Anne has demonstrated tremendous experience in nursing leadership, continued potential for leadership and significant commitment to the nursing profession through numerous initiatives promoting best practice. Previous winners of this award are Denise Malo (2001), Diana Hutchings (2002) and Janice Robinson (2003).

Because the Academy wishes to extend this critical support to more candidates in the future, we are exploring new funding opportunities. Remember as well that the Canadian Nurses Foundation and many provincial associations offer similar scholarships or bursary support to nurses continuing their education. See www.canadiannursesfoundation.com. 


\section{Patient Safety}

One of the Academy's four key priorities is ensuring improvements in patient safety. Two years ago, Wendy Nicklin (Ontario) and Heather Mass (BC) led an ACEN Workgroup to examine best practices in academic health science centres across Canada, and to join with other national partners in focusing greater attention on the many issues facing patients, nurses and other professionals. A number of articles have since been published by ACEN members relating to patient safety. One cannot address patient safety without also examining critically linked factors such as nursing workload. See our most recent publication in the last issue of CJNL (Ferguson-Paré 2004). And look forward soon to a joint position paper on patient safety between ACEN and the Association of Academic Healthcare Organizations (ACAHO) that will address the role of academic health science centres in shaping policies and best practices related to safety. This past year, the Academy was one of several nursing partners (with the Office of Nursing Policy and the Canadian Nurses Association) that lobbied successfully to obtain federal funds for much-needed equipment for nurses in supporting patient and staff safety.

In September 2002, the National Steering Committee on Patient Safety (NSCPS) issued a comprehensive report, Building a Safer System, that recommended a national integrated strategy for improving patient safety in Canadian healthcare. One of its key recommendations was the establishment of a Canadian Patient Safety
Institute (CPSI), designed to promote innovative solutions and to facilitate collaboration among governments and stakeholders to enhance patient safety. Following the Accord on Health Care Renewal, the 2003 Federal Budget provided $\$ 10$ million annually to support the NSCPS recommendations, including support for the creation of the CPSI.

In late winter, the Canadian Patient Safety Institute was created to provide a leadership role with respect to patient safety issues in the context of improving healthcare quality, by providing advice to governments, stakeholders and the public on effective strategies. Patient safety issues cut across the continuum of care, care settings and patient populations. The scope of the CPSI will be to examine priority issues in patient safety and bring forward what it considers to be the best practical information and strategies to support improvements in patient safety. The Institute will include in its work an analysis of perspectives from a wide range of system stakeholders. Two nurse leaders, Wendy Nicklin and Patricia Petryshen, are part of the nine-member CPSI Founding Board of Directors. The CPSI will

- foster the sharing of knowledge and information about optimal patient safety practices and models;

- influence change in culture and provide advice to support change in systems to improve patient safety; and

- collaborate with stakeholders in an ongoing dialogue to support patient safety improvements (Health Canada 2004). 
Below are some of the many patient safety research and best-practice links:

- Health Canada Online http://www.hc-sc.gc.ca/english/care/ patient_safety.html

- Royal College of Physicians and Surgeons of Canada http:// rcpsc.medical.org/ index.php?pass $=1$

- Canadian Council on Health Services Accreditation http://www.cchsa.ca/

- Health Quality Council Saskatchewan http://www.usask.ca/lists/hplink/ 2003/msg00062.html

- Institute for Safe Medication Practices Canada http://www.ismp-canada.org/

- Canadian Institute for Health Information http://secure.cihi.ca/cihiweb/ splash.html

- Canadian Institutes for Health Research

- Australian Council for Safety and Quality in Health Care http://www.cihr-irsc.gc.ca/ index.shtml

- AHRQ Electronic Newsletter http://www.ahrq.gov/news/ enewsix.htm

- National Healthcare Quality Report (NHQR)

http://www.ahrq.gov/qual/

- Nursing Best Practices Guidelines Project http://www.rnao.org/bestpractices/ about/bestPractice_overview.asp

- The CNA Patient Safety Resource Guide http://www.cna-nurses.ca/pages/ resources/patient_safety/resource_ guide.htm

- The Canadian Adverse Events Study http://secure.cihi.ca/cihiweb/ en/downloads/AdverseEvents_v2.pdf

\section{CHSRF Supporting Further Nursing Research}

Nursing research in Canada is growing. Did you know that in addition to federal and provincial funding for healthcare (including nursing) research, there is significant funding to support health service delivery research?

\section{CHSRF Extra Program}

EXTRA is a new strategic activity of the foundation whose primary goal is to give health system managers across Canada better skills to use research in their day-to-day work, as a way to increase evidence-based decisionmaking in the health system. The EXTRA program is supported by a group of partnering national organizations: the Canadian Health Services Research Foundation (CHSRF), the Canadian College of Health Service Executives (CCHSE), the Canadian Nurses Association (CNA), the Canadian Medical Association (CMA) and a consortium of Quebec partners represented by the Agence d'évaluation des technologies et des modes d'intervention en santé (AÉTMIS). Dr. Judith Ritchie (Québec) and Mrs. Wendy Nicklin (Ontario) are nursing representatives on the Extra Advisory Council.

Starting in May 2004 and continuing for at least 10 years, 24 fellows will enroll annually in the two-year 
Executive Training for Research Application (EXTRA) program. The aim of the program is to train mid-career health service professionals in senior management positions - nurse, physician and health administration executives - to find and apply research in their day-to-day work and facilitate evidence-based decision-making. The program will also provide these health service leaders with professional development and experiential learning opportunities.

Nine nurse executives, five physician leaders and 10 other healthcare executives constitute the first cohort. The nurses include: Maureen Cava, Toronto Public Health; J. Sonja Glass, Grey Bruce Health Services, Ontario; Deborah Ann Gordon, University of Alberta Hospital, Capital Health, Alberta; Heather L. Hoxby, St. Joseph's Hospital, Ontario; Kirsten Krull-Naraj, Royal Victoria Hospital, Ontario; Esther Leclerc, Centre Hospitalier de l'Université de Montréal, Québec; Patricia O'Connor, McGill University Health Centre, Quebec; Linda Sawchenko, Kootney Boundary Regional Hospital, British Columbia; and R. Lynn Stevenson, Fraser Health Authority, British Columbia (CHSRF 2004a).

\section{CHSRF Open Grants Competition}

The Canadian Health Services Research Foundation and the Canadian Institutes of Health Research (CIHR) have signed an agreement officially transferring the project component of the foundation's Open Grants Competition (OGC) to CIHR. "The transfer builds on the successful collaborative relationship developed by the two organizations since the inception of CIHR in 2000. This is a positive step to create synergy and reduce duplication in the funding of applied health services and policy research, including nursing, in Canada," says Jonathan Lomas, the foundation's CEO. Beginning with its fall 2004 call for proposals, CIHR will run the project competition and administer projects approved for funding prior to the 2004 competition. Information about the 2004/2005 OGC projects competition will be posted on CIHR's website (www.cihr-irsc.gc.ca) in late August.

The transfer of the project portion of the competition will almost certainly lead to greater availability of funds beginning in 2005. CIHR, through its institutes, will contribute $\$ 1$ million or more annually to the competition, and it will expand the themes to cover at least those identified as priorities from this year's Listening for Direction II exercise.

The foundation will continue to support the nursing community by providing up to $\$ 200,000$ annually to CIHR from the Nursing Research Fund to use as matching funds for projects funded under the theme of "nursing leadership, organization and policy." At the same time, the foundation will redesign the program model to ensure that junior researchers and regions with fewer resources will not be disadvantaged (CHSRF 2004b).

\section{Annual Conference of the Academy of Canadian Executive Nurses}

September 23rd and 25th are the dates for the upcoming annual conference of 
the Academy, and the annual ACAHO Invitational Conference will be September 23-24. ACEN has been invited to join ACAHO chief executive officers, vice-presidents of research and ACMC deans of research in a joint meeting focusing on the national research agenda.

\section{References}

Canadian Health Services Research Foundation. 2004a. "EXTRA Program." Retrieved July 20, 2004. $<$ http://www.chsrf.ca/extra/index_e.php $>$.

Canadian Health Services Research Foundation. 2004b. "Open Grants Competition." Retrieved July 20, 2004. <http://www.chsrf.ca/ funding_opportunities/ogc/transfer_e.php >.

Ferguson-Paré, M. 2004. "ACEN Position Statement: Nursing Workload - A Priority for Healthcare." Canadian Journal of Nursing Leadership 17(2): 24-26.

Health Canada. 2004 (June 28). "The Canadian Patient Safety Institute (CPSI) - Backgrounder.” Retrieved July 20, 2004. <http://www.hc-sc.gc.ca/ english/media/releases/2004/patient_safetybk1.html>.

Increases in Drug Spending Falling, CIHI Reports

According to a report by the Canadian Institute of Health Information (ClHI) yearto-year increases in drug spending are slowing down.

$\mathrm{CIHI}$ said total drug expenditures are forecast to have risen $7.2 \%$ in 2003 , a rate of increase considerably off the $9.7 \%$ pace between 1985 and 2001.

The report, Drug Expenditure in Canada, pointed out that prescribed drugs make up over $80 \%$ of drug costs, and the public sector is picking up an increasing share of the tab. In 2003, it is estimated the public sector will pay for $47.2 \%$ of the $\$ 16$ billion spent on prescribed drugs. This is up from $46.3 \%$ of $\$ 13$ billion in 2001 .

(Source: $\mathrm{ClHI}$ ) 